\title{
RelA regulates virulence and intracellular survival of Francisella novicida
}

Correspondence

R. E. Dean

redean@dstl.gov.uk

Received 19 May 2009

Revised 11 September 2009

Accepted 11 September 2009

\author{
R. E. Dean, ${ }^{1}$ P. M. Ireland, ${ }^{1}$ J. E. Jordan, ${ }^{1}$ R. W. Titball ${ }^{2}$ and P. C. F. Oyston ${ }^{1}$ \\ ${ }^{1}$ Biomedical Sciences, Dstl Porton Down, Salisbury, Wiltshire SP4 OJQ, UK \\ ${ }^{2}$ School of Biosciences, University of Exeter, Geoffrey Pope Building, Stocker Road, Exeter \\ EX4 4QD, UK
}

\begin{abstract}
Analysis of the genome of Francisella tularensis has revealed few regulatory systems, and how the organism adapts to conditions in different niches is poorly understood. The stringent response is a global stress response mediated by (p)ppGpp. The enzyme RelA has been shown to be involved in generation of this signal molecule in a range of bacterial species. We investigated the effect of inactivation of the relA gene in Francisella by generating a mutant in Francisella novicida. Under amino acid starvation conditions, the relA mutant was defective for (p)ppGpp production. Characterization showed the mutant to grow similarly to the wild-type, except that it entered stationary phase later than wild-type cultures, resulting in higher cell yields. The relA mutant showed increased biofilm formation, which may be linked to the delay in entering stationary phase, which in turn would result in higher cell numbers present in the biofilm and reduced resistance to in vitro stress. The mutant was attenuated in the J774A macrophage cell line and was shown to be attenuated in the mouse model of tularaemia, but was able to induce a protective immune response. Therefore, (p)ppGpp appears to be an important intracellular signal, integral to the pathogenesis of $F$. novicida.
\end{abstract}

\section{INTRODUCTION}

Francisella tularensis is an intracellular pathogen that causes the disease tularaemia. The organism can infect a wide range of hosts, including humans. Natural infection can occur following ingestion of contaminated food or water, bites by infected arthropod vectors, direct contact with infected animals or by inhalation (Ellis et al., 2002). The ecological niche of $F$. tularensis has not been identified, and little is known about the mechanisms utilized by the organism to persist in nature. Many outbreaks of $F$. tularensis have been associated with streams, ponds, lakes and rivers, and the bacterium is capable of surviving for more than a year in water and mud (Parker et al., 1951). Closely related Francisella-like organisms have been isolated from fish (Nylund et al., 2006; Ostland et al., 2006), which suggests that the natural niche of Francisella may be aquatic, although this remains to be confirmed.

Little is known regarding the molecular mechanisms of Francisella pathogenesis; however, as an intracellular pathogen, the ability to invade and multiply within macrophages is essential (reviewed by Oyston, 2008). Gene regulation in Francisella is poorly defined, and the elucidation of the genome sequence of $F$. tularensis has revealed few genes predicted to encode proteins with

Abbreviations: CV, crystal violet; FPI, Francisella pathogenicity island; MLD, median lethal dose; SPI, Salmonella pathogenicity island. regulatory functions (Larsson et al., 2005). A $30 \mathrm{~kb}$ Francisella pathogenicity island (FPI) has been identified which plays a role in intracellular multiplication (Nano et al., 2004). Disruption of many of the genes in the FPI, such as iglA, iglC, $p d p A$ and $p d p D$, results in attenuation in vitro or in vivo (Baron \& Nano, 1998; Golovliov et al., 2003; Gray et al., 2002; Lauriano et al., 2004; Lindgren et al., 2004; Nano et al., 2004). Genes of the FPI have been shown to be regulated by MglA, encoded by $m g l A$ (Lauriano et al., 2004), and SspA, encoded by sspA (Charity et al., 2007). MglA and MglB are essential for intracellular replication and virulence in mice (Baron \& Nano, 1998; Lauriano et al., 2004), and share homology with the Escherichia coli SspA and SspB proteins, which are regulators of stationary phase transcription and are involved in stress survival (Williams et al., 1994). Apart from MglA and SspA, few regulators have been identified in Francisella. Considering the wide range of cell types, including amoebae, that the organism can parasitize, and that it can survive extracellularly and within arthropod vectors, the organism must exploit its relatively small $(1.8 \mathrm{Mbp})$ genome highly efficiently to respond to changing environments and stress. In this respect it is similar to another intracellular pathogen, Neisseria gonorrhoeae, which also possesses few regulators to mediate adaptation to environmental change (Parkhill et al., 2000; Tettelin et al., 2000).

Many bacterial species resist environmental stress in part by induction of the stringent response (Jain et al., 2006), 
mediated by production of hyperphosphorylated guanosine diphosphate and triphosphate analogues, collectively termed (p)ppGpp. During nutrient starvation, uncharged tRNA molecules bind to the ribosome, which results in ribosome stalling. This activates ribosome-associated RelA and catalyses the production of pppGpp, which is subsequently converted to ppGpp. The ppGpp molecule binds to RNA polymerase to affect expression of a range of physiological systems, including $\sigma^{s}$, an alternative sigma factor. The net effect is a reduction in transcription, but a large number of $\sigma^{70}$-dependent genes are induced, as are proteins involved in proteolysis and amino acid biosynthesis. In some bacteria, inactivation of both relA and spoT is required to completely abolish (p)ppGpp synthesis; SpoT is a bifunctional enzyme capable of both synthesis and degradation of the signal molecule, so preventing uncontrollable accumulation of (p)ppGpp (Jain et al., 2006). The relA and spoT genes are restricted to the betaproteobacteria and gammaproteobacteria (Mittenhuber, 2001), and it has been proposed that the RelA-dependent response is linked to amino acid starvation and that the SpoT-dependent response is linked to fatty acid metabolism in these bacteria (Battesti \& Bouveret, 2009). In some pathogens regulation of (p)ppGpp synthesis is dependent on SpoT, and virulence in Legionella pneumophila is critically dependent on the degradation of (p)ppGpp by SpoT (Dalebroux et al., 2009). Both relA and spoT genes have been annotated in the Francisella novicida U112 (Rohmer et al., 2006) and F. tularensis SCHU S4 (Larsson et al., 2005) genome sequences; however, the functions of these enzymes in Francisella have not yet been defined.

The stringent response, induced by nutrient limitation, has been demonstrated in a range of bacteria, including Escherichia coli (Magnusson et al., 2005), N. gonorrhoeae (Fisher et al., 2005), Streptococcus suis (Li et al., 2009) and Borrelia burgdorferi (Bugrysheva et al., 2003b), and it appears that most bacteria require the stringent response for stationary phase survival (Mouery et al., 2006; Bugrysheva et al., 2003a). In addition, RelA has been shown to be involved in regulation of other diverse phenotypes, including biofilm formation by Streptococcus mutans (Lemos et al., 2004), osmotolerance of Listeria monocytogenes (Okada et al., 2002), stress response, vancomycin tolerance and virulence of Enterococcus faecalis (Abranches et al., 2009), and anaerobiosis in Mycobacterium tuberculosis (Sureka et al., 2007).

The stringent response has been shown to play an important role in the life cycle and virulence of intracellular pathogens. For example, in Legionella pneumophila, (p)ppGpp triggers a switch between the avirulent replicative phase and the virulent motile phase (Hammer \& Swanson, 1999), while in M. tuberculosis, (p)ppGpp accumulation is important for the transition into latency (Ojha et al., 2000; Primm et al., 2000). In addition, the expression of specific virulence genes has been shown to be modified by RelA: in Vibrio cholerae, inactivation of RelA results in decreased expression of cholera toxin and the toxin-coregulated pilus (Haralalka et al., 2003), and a
Salmonella enterica spoT/relA mutant has reduced expression of HilA, the central regulator of the Salmonella pathogenicity island (SPI) 1 and SPI 2 virulence genes (Pizarro-Cerda \& Tedin, 2004).

In light of the paucity of information on regulation of gene expression in F. tularensis, and with the growing evidence of the role of (p)ppGpp as a global regulator of phenotypes associated with both in vivo and environmental survival, this study was undertaken to determine the effect of inactivation of RelA on F. novicida.

\section{METHODS}

Bacterial strains and culture conditions. F. novicida strain U112 was obtained from the American Type Culture Collection. The strain was grown on blood cysteine glucose agar (BCGA) supplemented with $4 \%$ cysteine, $4 \%$ histidine, $5 \%$ glucose and $10 \%$ fresh filtered horse blood, or on Thayer-Martin agar (Milne et al., 2007). Where required, media were supplemented with $100 \mu \mathrm{g}$ polymixin $\mathrm{B} \mathrm{ml}^{-1}$, $10 \mu \mathrm{g}$ chloramphenicol $\mathrm{ml}^{-1}$ and $10 \%(\mathrm{w} / \mathrm{v})$ sucrose. Growth of strain U112 in liquid culture was supported by Chamberlain's defined medium (CDM) (Chamberlain, 1965) with aeration, or modified Chamberlain's defined medium lacking serine $\left(\mathrm{CDM}^{-} \mathrm{S}\right)$ or with reduced $\mathrm{PO}_{4}$ at $2 \mathrm{mM}\left(\mathrm{CDM}_{2}\right)$ or at $0.4 \mathrm{mM}\left(\mathrm{CDM}_{0.4}\right)$. E. coli strains

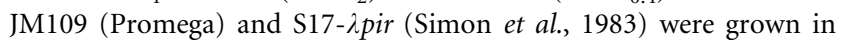
Luria-Bertani medium at $37{ }^{\circ} \mathrm{C}$, supplemented as required with $30 \mu \mathrm{g}$ chloramphenicol $\mathrm{ml}^{-1}$.

DNA manipulation. Generally, the manipulation of DNA was carried out using standard protocols (Sambrook et al., 1989). Genomic DNA was isolated using the Puregene DNA Isolation kit (Gentra Systems). Plasmid DNA was isolated using the Qiagen mini and maxi plasmid isolation kits. Primers and plasmids used in this study are described in Table 1. Southern blotting was performed under high-stringency conditions (Sambrook et al., 1989).

Generation of the $\Delta$ relA mutant. Oligonucleotide primers (Table 1) were designed from the $F$. tularensis SCHU S4 genome sequence, such that an 1877 bp internal region would be deleted. DNA flanking the relA gene was amplified by PCR following 30 cycles of amplification $\left(94{ }^{\circ} \mathrm{C}, 30 \mathrm{~s} ; 55^{\circ} \mathrm{C}, 30 \mathrm{~s} ; 72^{\circ} \mathrm{C}, 1 \mathrm{~min}\right.$ ) (Perkin Elmer 9600 GeneAmp PCR system). Each product was ligated into pGEM-T Easy according to the manufacturer's instructions (Promega) and transformed into E. coli JM109. The inserts were isolated following digestion with $E c o$ RI and $B a m H I$ and linked in a three-way ligation with pUC18 which had been digested with EcoRI. The insert was subsequently subcloned into pUCB, a derivative of pUC18 wherein the $B a m \mathrm{HI}$ restriction site had been abolished by treatment with Klenow fragment. The BamHI restriction site in primers relR1 and relF2 allowed the insertion of the chloramphenicol resistance cassette from pGEMCAMBamH1 between the two flanks. The whole insert was isolated by digestion with $M l u \mathrm{I}$ and ligated into similarly digested pPV2 J to generate pPVrel. The plasmid was transformed into E. coli S17- $\lambda$ pir by electroporation, and mobilized into F. novicida strain U112 by conjugation. Conjugation was performed on BCGA at $25{ }^{\circ} \mathrm{C}$ overnight. The bacteria were then removed and plated on ThayerMartin agar supplemented with polymixin B (to select against the $E$. coli) and chloramphenicol. Sucrose selection was subsequently performed to identify recombinants in which the plasmid was excised. The mutant was confirmed by PCR and Southern blotting and designated F. novicida U112 $\Delta$ relA : : cam.

The mutant was complemented by insertion of the entire coding sequence of the $F$. tularensis relA gene. The gene was amplified by 
Table 1. Oligonucleotide primers and plasmids used in this study

Underlined sequences represent restriction sites introduced into oligonucleotide sequences to facilitate cloning.

\begin{tabular}{|c|c|c|}
\hline Primer & \multicolumn{2}{|c|}{ Restriction site included } \\
\hline relF1 & ACGCGTCTAAGATAGCCGTTAGTAGC & $M l u \mathrm{I}$ \\
\hline relR1 & GGATCCGGGATGATAATGAAGAGGTC & BamHI \\
\hline relF2 & $\overline{\text { GGATCCCTGACCATCACTATCTAGAAG }}$ & BamHI \\
\hline relR2 & ACGCGTCCCAGCAATTAGGAACTAC & $M l u \mathrm{I}$ \\
\hline crelF & GGTACCATGCAAGTTATTGACTCTA & KpnI \\
\hline crelR & GGTACCATTATTAGCTGACCTCTTC & KpnI \\
\hline Plasmid & Description & Source or reference \\
\hline pUC18 & $A m p^{R}$ & \\
\hline pUCB & pUC18 with inactivated $\mathrm{BamHI}$ restriction site & This study \\
\hline pDM4 & $\mathrm{Cam}^{\mathrm{R}}$ & Milton et al. (1996) \\
\hline pGEMCAMBamH1 & $\begin{array}{l}\text { pGEM-T Easy (Promega) containing the } \mathrm{Cam}^{\mathrm{R}} \text { cassette from pDM4 amplified by } \\
\text { PCR to be flanked by BamHI restriction sites; } \mathrm{Amp}^{\mathrm{R}}\end{array}$ & Quarry et al. (2007) \\
\hline pRel12 & pUC18 containing the $\Delta r e l A$ insert & This study \\
\hline pRelCam & $\begin{array}{l}\text { pRel12 with chloramphenicol resistance cassette inserted at the BamHI restriction } \\
\text { site between the two flanks of the deletion insert }\end{array}$ & This study \\
\hline pPV2 J & Derivative of pPV2 with inactivated $\mathrm{Cam}^{\mathrm{R}}$; oriT; bla; $s a c B$ & Quarry et al. (2007) \\
\hline pPVrel & $\begin{array}{l}\text { Donor plasmid for conjugation; sacB; pPV2 J containing mutated } \Delta \text { relA:: cam } \\
\text { fragment from pRelCam }\end{array}$ & This study \\
\hline pSMP6OriT & Stable plasmid for complementation studies in Francisella; Tet $^{\mathrm{R}}$ & Quarry et al. (2007) \\
\hline pSMP6OriT.relA & $\begin{array}{l}\text { Complementation plasmid expressing RelA driven by the Francisella GroES } \\
\text { promoter }\end{array}$ & This study \\
\hline
\end{tabular}

PCR using primers crelF and crelR, and the product ligated into pSMP6OriT, conferring tetracycline resistance, which had been digested with $K p n \mathrm{I}$, to give pSMP6OriT.relA. The plasmid was mobilized into the U112 $\Delta$ relA: : cam mutant by conjugation to give U112 $\Delta$ relA : : cam prelA. Transformants were selected for on ThayerMartin agar supplemented with polymixin B and tetracycline and confirmed by PCR.

(p)ppGpp detection assay. The method of Cashel (1994) was adapted to determine levels of (p)ppGpp produced by Francisella. Cells were passaged three times in $20 \mathrm{ml} \mathrm{CDM}^{-} \mathrm{S}$, with aeration at $37{ }^{\circ} \mathrm{C}$ for $24 \mathrm{~h}$ each passage. Bacteria were subcultured into $20 \mathrm{ml}$ reduced $\mathrm{PO}_{4} \mathrm{CDM}_{2}^{-} \mathrm{S}$ and incubated for $18 \mathrm{~h}$ with aeration at $37^{\circ} \mathrm{C}$. Cells were harvested by centrifugation at $2500 \mathrm{~g}$ for $10 \mathrm{~min}$ and washed twice with minimal $\mathrm{PO}_{4} \mathrm{CDM}_{0.4}{ }^{-} \mathrm{S}$. Cells were adjusted to $\mathrm{OD}_{600} 0.1$ and incubated with aeration at $37^{\circ} \mathrm{C}$ to $\mathrm{OD}_{600} \sim 0.2$, at which point $1 \mu \mathrm{l}\left[{ }^{32} \mathrm{P}_{3} \mathrm{H}_{3} \mathrm{PO}_{4}\right.$ (Perkin-Elmer) was added to each culture to give a final concentration of $10 \mu \mathrm{Ci} \mathrm{ml})^{-1}(0.37 \mathrm{MBq}$ $\mathrm{ml}^{-1}$ ). After further incubation for $2 \mathrm{~h}, 2.5 \mathrm{mg}$ serine hydroxamate $\mathrm{ml}^{-1}$ was added to cultures to induce serine-starvation conditions. After $30 \mathrm{~min}$ incubation, nucleotides were extracted by adding an equal volume of ice-cold $13 \mathrm{M}$ formic acid, and samples were subjected to three freeze-thaw cycles. Nucleotides were separated on polyethylenemine TLC cellulose plates (Sigma-Aldrich) and visualized by exposure on a phosphorimaging plate. Controls consisting of radiolabelled (p)ppGpp isolated from E. coli K-12 and GTP (Perkin Elmer) were run alongside.

Microtitre biofilm assay. Bacteria were prepared for biofilm experiments by harvesting cells from BCGA plates and resuspending them in $\mathrm{CDM}$ to $\mathrm{OD}_{540} 0.2$, which equated to a suspension of $\sim 1 \times 10^{9}$ c.f.u. $\mathrm{ml}^{-1}$, and then diluted $1: 10$. The microtitre biofilm assay was performed as described by Stepanovic et al. (2000) with minor modifications. Eight wells on a 96-well microtitre plate (Costar 3595) were each filled with $200 \mu \mathrm{l}$ bacterial suspension. The outer wells were filled with distilled water to reduce evaporation from the test samples. Plates were incubated at $37{ }^{\circ} \mathrm{C}$ for 6 days. To measure biofilm formation, each well was washed three times with PBS, to remove all non-adherent cells. Remaining attached cells were fixed by the addition of $200 \mu \mathrm{l} 99 \%$ methanol. Methanol was removed and plates were left to air dry. Biofilms were stained by the addition of $200 \mu \mathrm{l}$ of $2 \%$ Huckers crystal violet (CV) for $5 \mathrm{~min}$. Excess stain was removed by pipette, followed by submersion of the plate in $300 \mathrm{ml}$ fresh tap water, three times. Plates were air-dried, after which the dye bound to the adherent cells was resolubilized by the addition of $200 \mu \mathrm{l}$ $33 \%(\mathrm{v} / \mathrm{v})$ glacial acetic acid. The $A_{570}$ of each well was measured using a microtitre plate reader (MultiSkan EX, Thermo), following 10 s shaking.

Intramacrophage survival assay. J774A murine macrophages were infected at an m.o.i. of 5 and incubated at $37^{\circ} \mathrm{C}$ for $30 \mathrm{~min}$. Extracellular bacteria were killed with $10 \mu \mathrm{g}$ gentamicin $\mathrm{ml}^{-1}$ for $30 \mathrm{~min}$. Cultures were maintained in L-15 tissue culture medium (Sigma-Aldrich) containing $2 \mu \mathrm{g}$ gentamicin $\mathrm{ml}^{-1}$ at $37{ }^{\circ} \mathrm{C}, 5 \% \mathrm{CO}_{2}$ until harvesting at various times post-infection. Macrophages were disrupted by the addition of $1 \mathrm{ml}$ distilled $\mathrm{H}_{2} \mathrm{O}$ and aspiration 30 times. Bacteria were enumerated by plating onto BCGA and incubating for 3 days at $37^{\circ} \mathrm{C}$.

Determination of attenuation in mice. Groups of six female BALB/ c mice (Charles River Laboratories) aged 6-8 weeks were challenged subcutaneously with $\sim 10^{4}, 10^{5}$ or $10^{6}$ c.f.u. of $F$. novicida U112 $\Delta$ relA:: cam. The bacteria for challenge were harvested after growth for $18 \mathrm{~h}$ at $37{ }^{\circ} \mathrm{C}$ on BCGA agar. Mice were challenged on day 56 post-vaccination with $\sim 10^{2}$ c.f.u. F. novicida U112 via the intraperitoneal route. Actual doses were determined by retrospective viable 
counts. All procedures were carried out in accordance with UK Home Office guidelines. Animals were observed for signs to indicate humane end points, and these were used to direct culling.

Statistics. Statistical differences in cell densities were determined using two-way ANOVA, repeated measures ANOVA with Bonferroni's multiple comparisons test, or $t$ test. Survival data were analysed using a Mantel-Cox log-rank test. All statistical analyses were performed using GraphPad Prism v5.01.

\section{RESULTS}

\section{An $F$. novicida relA mutant is unable to produce (p)ppGpp under conditions of amino acid limitation}

To investigate the role of RelA in Francisella, FTN_1518, annotated to encode a (p)ppGpp synthetase in F. novicida strain U112, was targeted for inactivation and a defined $\Delta r e l A:$ cam mutant was created. The mutant had an internal $1877 \mathrm{bp}$ fragment of the relA gene deleted and replaced with a chloramphenicol resistance cassette. It was not expected that this would have polar effects, based on the orientation and separation of adjacent genes. However, to confirm that phenotypes were specifically due to inactivation of relA, the mutation was complemented by a constitutively expressed plasmid-encoded copy of the relA gene.

It has been reported that RelA-dependent synthesis of (p)ppGpp occurs during amino acid starvation in conjunction with growth arrest; therefore, serine starvation was induced by adding serine hydroxamate to cultures. This study determined that $2.5 \mathrm{mg}$ serine hydroxamate $\mathrm{ml}^{-1}$ completely inhibited growth of F. novicida U112 (data not shown); therefore, these culture conditions were used to induce serine starvation. To confirm the function of RelA in F. novicida, the ability of the wild-type strain U112 $\Delta$ relA::cam and the complemented mutant strain U112 $\Delta$ relA:: cam pRelA to produce (p)ppGpp was assessed. Bacteria were cultured in serine-free CDM supplemented with ${ }^{32} \mathrm{P}$, and serine hydroxamate was added to exponentially growing cultures to induce starvation. Extraction and separation of nucleotides from these cultures by TLC demonstrated (p)ppGpp production by the wild-type strain during starvation conditions. Conversely, (p)ppGpp was undetectable in U112 $\Delta r e l A:$ :cam under the same conditions, and the production of (p)ppGpp was restored when the mutation was complemented in U112 $\Delta$ relA : : cam pRelA (Fig. 1).

\section{F. novicida U112 $\Delta$ relA : : cam has growth kinetics similar to those of the wild-type in vitro, but has delayed entry into stationary phase}

In other bacteria, disruption of the relA gene can result in reduced growth rates and stationary phase growth defects (Lemos et al., 2004; Gaynor et al., 2005; Fisher et al., 2005; Milne et al., 2007; Mouery et al., 2006); therefore, the effect

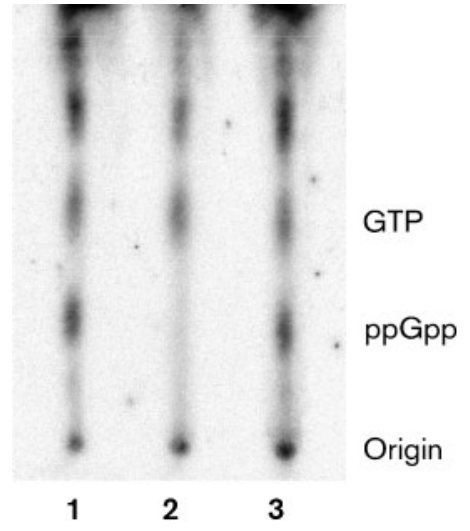

Fig. 1. (p)ppGpp accumulation in F. novicida U112 (lane 1), U112 $\Delta r e / A$ : : cam (lane 2) and U112 $\Delta r e / A$ : : cam pRelA (lane 3). Cultures were passaged daily in $\mathrm{CDM}^{-} \mathrm{S}$ for 3 days, prior to overnight culture in $\mathrm{CDM}^{-} \mathrm{S}\left(2 \mathrm{mM} \mathrm{PO}_{4}\right)$. Bacteria were adjusted to $\mathrm{OD}_{600} 0.1$ in $\mathrm{CDM}^{-} \mathrm{S}\left(0.4 \mathrm{mM} \mathrm{PO}_{4}\right)$ and grown for $3 \mathrm{~h}$ with shaking at $37{ }^{\circ} \mathrm{C}$. $\left[{ }^{32} \mathrm{P}\right] \mathrm{H}_{3} \mathrm{PO}_{4}$ was added to each culture to a final concentration of $10 \mu \mathrm{Ci} \mathrm{ml}^{-1}\left(0.37 \mathrm{MBq} \mathrm{ml}^{-1}\right)$, and incubated for a further $2 \mathrm{~h}$. To induce (p)ppGpp production, $2.5 \mathrm{mg}$ serine hydroxamate $\mathrm{ml}^{-1}$ was added and cultures were incubated for $30 \mathrm{~min}$. Radionucleotides were detected by phosphorimaging following separation by TLC. Positive controls of GTP and (p)ppGpp were included (not shown).

of deletion of the relA gene on the ability of Francisella to grow in liquid media was evaluated. During exponential phase, U112 $\Delta$ relA:: cam had a similar growth rate to the wild-type. However, the mutant entered stationary phase later and grew to significantly higher cell densities than the wild-type $(P<0.001)$ (Fig. 2a). The wild-type phenotype was partially restored when the mutation was complemented (Fig. 2b). Using a repeated measures ANOVA with Bonferroni's multiple comparisons test, the density of the mutant was found to be significantly different from that of the wild-type and complemented strain $(P<0.01)$.

To further investigate this growth phenomenon, the ability of U112 $\Delta$ relA : : cam to form biofilms was examined. RelA has been demonstrated to be necessary for efficient biofilm formation in several bacteria (Lemos et al., 2004; Balzer \& Mclean, 2002), possibly by reducing the nutrient levels surrounding microcolonies as the biofilm matures. Interestingly in our studies, the rate and quantity of biofilm production by U112 $\triangle$ relA: : cam were greater than those of the wild-type strain, as indicated by $\mathrm{CV}$ staining $(P<0.01)$ (Fig. 3).

\section{Induction of RelA is involved in resistance of Francisella to stress}

In order to survive the different conditions experienced both in the environment and in the host, bacteria must tightly regulate their gene expression. RelA has been reported to be involved in resistance to different stresses 


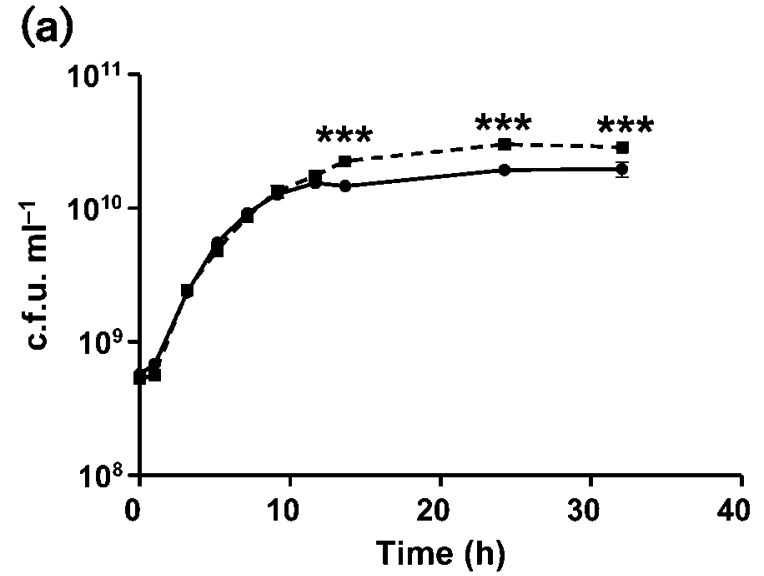

(b)

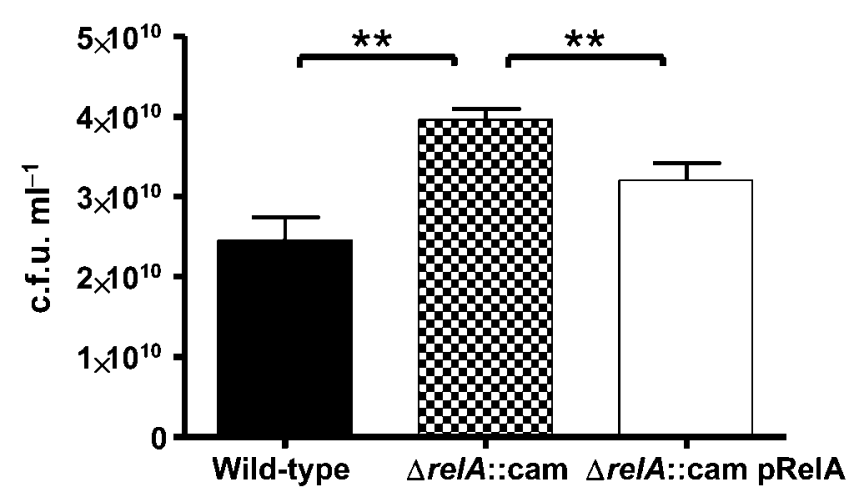

Fig. 2. Growth of $F$. novicida in CDM in shaking cultures. (a) $F$. novicida U112 ( ) or U112 $\Delta$ relA : : cam (ם) were grown in CDM at $37{ }^{\circ} \mathrm{C}$ with shaking at 150 r.p.m. Samples were taken at various time points and bacteria enumerated on BCGA plates. Data points represent means and SEM of triplicate experiments $\left({ }^{\star \star \star} P<0.001\right)$. (b) F. novicida U112 (black bar), U112 $\Delta$ relA: : cam (chequered bar) or U112 $\Delta$ relA : : cam pRelA (white bar) were grown at $37{ }^{\circ} \mathrm{C}$ with shaking at 150 r.p.m. for 24 h. Bacteria were harvested and enumerated on BCGA plates. Data are presented as means and SEM of four experiments $\left({ }^{\star \star} P<0.01\right)$.

in many bacteria, including tolerance of heat stress of Enterococcus faecalis (Abranches et al., 2009). Using heat stress as an indicator of stress survival, the ability of the U112 $\Delta$ relA::cam mutant to survive exposure to heat stress was investigated. The survival of cultures after incubation at $48{ }^{\circ} \mathrm{C}$ for $1 \mathrm{~h}$ was determined by viable counts, and compared with that at $37{ }^{\circ} \mathrm{C}$ (Fig. 4). At $48{ }^{\circ} \mathrm{C}$, survival of both the wild-type and U112 $\Delta$ relA: : cam was reduced compared with survival at $37{ }^{\circ} \mathrm{C}$. To test whether inducing the stringent response would increase thermotolerance, strains were exposed to serine hydroxamate to mimic serine starvation prior to incubation at 37 and $48{ }^{\circ} \mathrm{C}$ (Fig. 4). Wild-type bacteria demonstrated similar levels of survival at 48 and $37{ }^{\circ} \mathrm{C}$, indicating increased survival in serine-starved cultures; however, U112 $\Delta$ relA : : cam counts were significantly reduced at $48{ }^{\circ} \mathrm{C}$ compared with $37{ }^{\circ} \mathrm{C}$

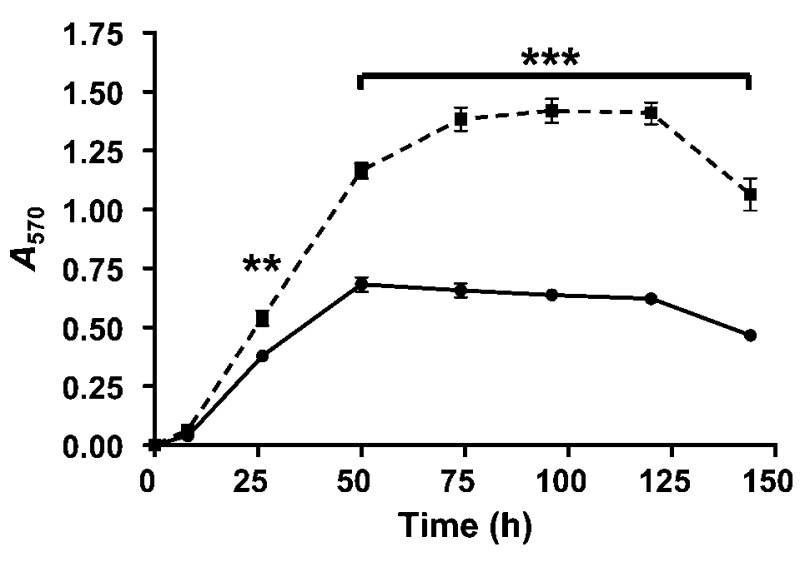

Fig. 3. Determination of biofilm formation by F. novicida U112 (O) or U112 $\Delta$ relA::cam (ם) in CDM in static cultures. Data are presented as means and SEM of 24 cultures $\left({ }^{* *} P<0.01\right.$, $\left.{ }^{\star * *} P<0.001\right)$.

$(P=0.03)$. These data suggest that increased survival at $48{ }^{\circ} \mathrm{C}$ requires prior induction of the stringent response in a RelA-dependent manner.

\section{F. novicida U112 $\Delta$ relA : : cam has reduced ability to replicate in macrophages in vitro}

The stringent response has been reported to be involved in intracellular survival in many pathogens, such as Campylobacter jejuni (Gaynor et al., 2005), L. monocytogenes (Taylor et al., 2002) and Brucella abortus (Kim et al., 2005). To examine whether the attenuation observed in vivo is due to a defect in intracellular survival, the ability of U112 $\Delta$ relA::cam to infect and replicate within murine

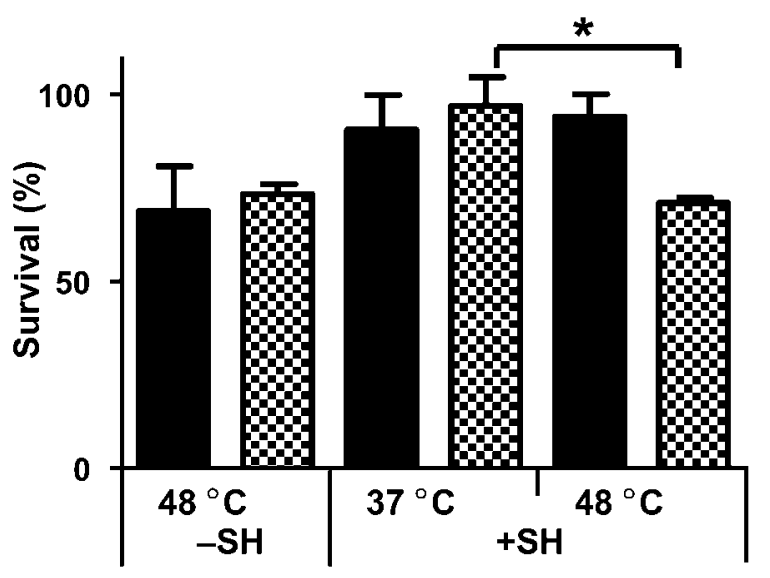

Fig. 4. Effect of RelA on thermotolerance of Francisella. Survival of $F$. novicida $\mathrm{U} 112$ (black bars) or U112 $\Delta$ relA : : cam (chequered bars) at $48{ }^{\circ} \mathrm{C}$ before and after serine starvation [induced by the addition of serine hydroxamate $(\mathrm{SH})]$. Data are presented as means and SEM of three experiments $\left({ }^{*} P=0.03\right)$. 
macrophages was assessed (Fig. 5). The uptake of wild-type and U112 $\Delta$ relA : : cam was similar at $0 \mathrm{~h}$ post-infection. A mild reduction in replication at 24 and $48 \mathrm{~h}$ post-infection was observed in U112 $\Delta$ relA:: cam cultures compared with the wild-type, yet was statistically significant $(P<0.05)$. Survival of the complemented strain U112 $\Delta$ relA::cam pRelA was similar to that of the wild-type at 0,24 and $48 \mathrm{~h}$ post-infection.

\section{F. novicida U112 $\Delta$ relA : : cam is attenuated in vivo and is able to induce a protective immune response}

RelA has been suggested to be involved in virulence of several pathogens; therefore, the virulence of U112 $\Delta r e l A::$ cam in a BALB/c mouse model of infection was assessed. Groups of mice were challenged subcutaneously with $8.4 \times 10^{3}, 8.4 \times 10^{4}$ and $8.4 \times 10^{5}$ c.f.u. of wild-type strain U112 or U112 $\Delta$ relA : : cam and observed for 14 days (Fig. 6a). All animals survived challenge with U112 $\Delta$ relA::cam, with the exception of one mouse from the highest dose group. Animals challenged with the wild-type strain had succumbed to infection by day 4 post-challenge. The median lethal dose (MLD) for F. novicida U112 has been previously calculated as $3.4 \times 10^{2}$ c.f.u. by the subcutaneous route (Milne et al., 2007). These results demonstrate a significant increase in survival $(P=0.001)$ when mice were challenged with U112 $\Delta$ relA::cam, demonstrating that this mutant was attenuated $>100$ fold. To test whether U112 $\Delta$ relA : : cam was able to stimulate a protective immune response, the surviving animals were challenged 56 days later with $6 \times 10^{3}$ c.f.u. (equivalent to 600 MLD) of wild-type F. novicida U112 by the intraperitoneal route and observed for 14 days (Fig. 6b).

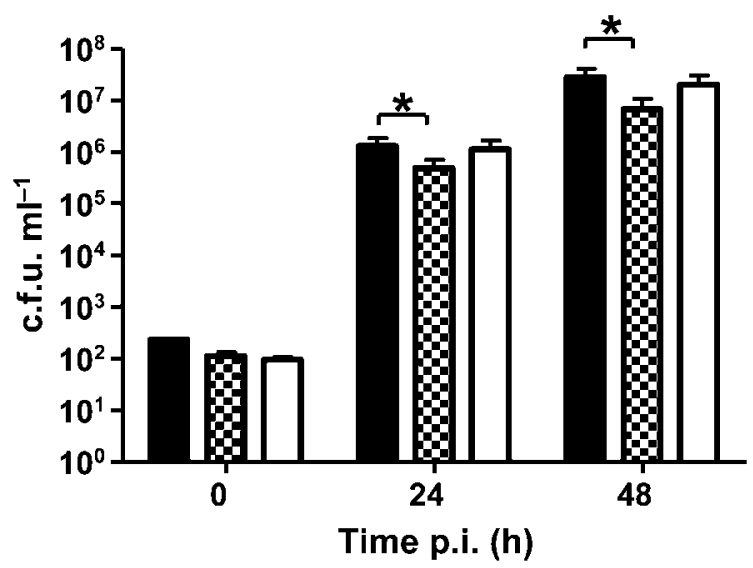

Fig. 5. Survival of $F$. novicida U112 (black bars), U112 $\Delta r e / A$ : : cam (chequered bars) or U112 $\Delta r e / A$ : : cam pRelA (white bars) in J774A cells. Cells were infected at m.o.i. 5 , and intracellular bacteria were harvested and enumerated at 0,24 and $48 \mathrm{~h}$ postinfection (p. i.). Data are presented as means and SEM of triplicate wells, performed on three separate occasions $\left({ }^{*} P<0.05\right)$. (a)

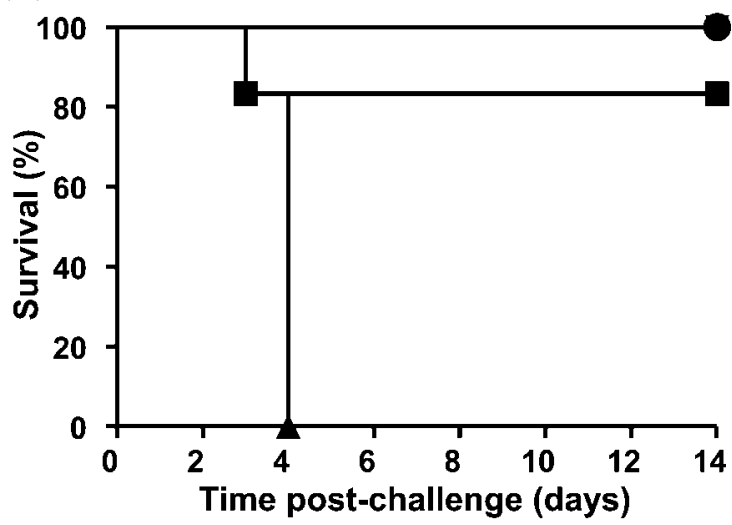

(b)

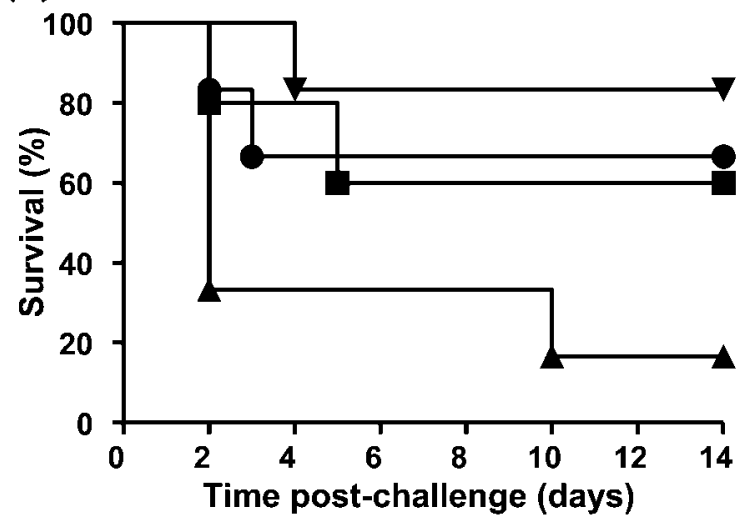

Fig. 6. Effects of inactivation of relA on virulence of $F$. novicida $\mathrm{U} 112$ in BALB/c mice. (a) Groups of six mice were challenged by the subcutaneous route with $8.4 \times 10^{3}(\boldsymbol{\nabla}), 8.4 \times 10^{4}(\boldsymbol{O})$ or $8.4 \times 10^{5}(\mathbf{\square})$ c.f.u. U112 $\Delta$ relA: : cam or $1 \times 10^{4}$ c.f.u. wild-type strain U112 ( $\mathbf{\Delta})$. (b) Surviving animals and six naïve animals ( $\mathbf{A})$ were challenged intraperitoneally 56 days later with 600 MLD wild-type F. novicida U112.

Survival of mice immunized with the lowest U112 $\Delta$ relA::cam dose was significantly increased compared with that of naïve animals $(P=0.02)$. These results demonstrated that vaccination with $F$. novicida U112 $\Delta$ relA:: cam induced high levels of protective immunity against wild-type $F$. novicida infection in vivo.

\section{DISCUSSION}

F. tularensis must closely regulate gene expression to maximize survival in response to changes in environmental conditions or varying niches. However, few regulators, such as two-component regulatory systems, have been identified (Mohapatra et al., 2007). Other regulatory systems may therefore be important for $F$. tularensis virulence and survival. For example, polyphosphate has been shown to be important in the stress responses of a range of pathogens, including $F$. tularensis (Richards et al., 
2008). Polyphosphate has also been shown to be required for virulence for a range of pathogens, possibly by contributing to (p)ppGpp (Manganelli, 2007).

Two proteins well characterized for their role in (p)ppGpp metabolism are RelA and SpoT. RelA catalyses the production of (p)ppGpp, which is subsequently converted to ppGpp, while SpoT is a bifunctional enzyme capable of both synthesis and degradation of the signal molecule (Jain et al., 2006). Both relA and spoT homologues are present in the Francisella genome. In some bacteria, inactivation of both relA and spoT is required to completely abolish (p)ppGpp synthesis, while in other bacteria, RelA is dominant in (p)ppGpp synthesis. In this study, we have confirmed the role of FTN_1518 in F. novicida U112 as a (p)ppGpp synthetase, and demonstrated that disruption of this gene results in abolition of ppGpp production under conditions of amino acid starvation. This is similar to the situation in Pseudomonas aeruginosa (Erickson et al., 2004) and V. cholerae (Haralalka et al., 2003), in which mutation of the relA gene alone results in reduced (p)ppGpp accumulation. Unlike other organisms such as E. coli, in which both relA and spoT genes need to be inactivated (Xiao et al., 1991), RelA alone appears to be required for (p)ppGpp synthesis in F. novicida during amino acid starvation.

The role of (p)ppGpp in Francisella appears to be complex, as disruption of the relA gene did not result in a reduced growth rate, a stationary phase defect or reduced biofilm formation, as reported in other bacteria (Fisher et al., 2005; Lemos et al., 2004; Okada et al., 2002). Many basic questions remain unanswered as to how (p)ppGpp exerts its effects, but it is thought that (p)ppGpp acts at the level of transcription, targeting RNA polymerase (Potrykus \& Cashel, 2008). It has been proposed that growth defects observed in relA mutants can be attributed to the lack of (p)ppGpp-dependent expression of the rpoS gene, which encodes $\sigma^{\text {S }}$ (Gentry et al., 1993). This alternative sigma factor controls expression of genes or operons involved in protecting cells from stress, including stationary phase survival, high osmolarity, oxidative damage and acidic $\mathrm{pH}$ (Kazmierczak et al., 2005). It is thought that (p)ppGpp increases the ability of both $\sigma^{\mathrm{S}}$ and $\sigma^{32}$ to compete with the vegetative sigma factor $\sigma^{70}$ for RNA polymerase (Jishage et al., 2002), presumably resulting in increased expression of $\sigma^{\mathrm{S}}$-induced general stress response and $\sigma^{32}$-dependent heat-shock response genes. Interestingly, in silico studies have only identified the $\sigma^{32}$ and $\sigma^{70}$ subunits in Francisella, and the other subunits are absent (Meibom et al., 2008). The decreased ability of $F$. novicida to survive heat shock suggests a role for RelA in combating stress encountered during the infectious process, perhaps in a $\sigma^{32}$-dependent manner (Meibom et al., 2008), where (p)ppGpp is the trigger. A similar role for RelA in resistance to heat stress has been reported in Enterococcus faecalis, where RelA is responsible for resistance to stress, whereas an alternative synthase RelQ is responsible for maintaining basal levels of (p)ppGpp (Abranches et al., 2009).
The ability of U112 $\Delta$ relA:: cam to grow to higher cell densities as planktonic and biofilm cultures is unusual, but similar effects have been observed in $\Delta r e l A \Delta$ spoT mutants of $E$. coli, which demonstrate more rapid growth (Xiao et al., 1991) and increased biofilm formation in nutrientrich media (Balzer \& Mclean, 2002). It appears that $F$. novicida U112 $\Delta$ relA::cam is not able to respond to nutrient depletion, as a result of being unable to invoke the RelA-dependent stringent response. Bacterial cells in stationary phase are very different from exponentially growing bacteria. For example, stationary phase cells are smaller than those in exponential phase, have more robust membranes due to changes in lipid composition, and more highly cross-linked peptidoglycan (Davis et al., 1980; Ingraham et al., 1983). By monitoring nutrient levels in the surrounding environment and adjusting gene expression, for example by the stringent response, bacteria can prepare for stationary phase to optimize their survival when nutrients are depleted. The U112 $\Delta$ relA::cam mutant does not appear to modulate its growth rate in response to declining nutrient levels when it should be preparing for stationary phase. It is not known whether growth is finally arrested as a result of nutrient limitation or whether another regulatory pathway subsequently arrests growth.

Bacterial intracellular accumulation of (p)ppGpp has a direct effect on virulence, invasion, pathogenesis and host immune system evasion. Many pathogens have evolved survival strategies triggered by (p)ppGpp (Braeken et al., 2006). For example, accumulation of (p)ppGpp in Salmonella appears to induce HilA expression, which in turn regulates expression of SPI 1 and SPI 2 virulence genes (Thompson et al., 2006; Song et al., 2004). The SPI 1 genes are involved in host cell invasion and the SPI 2 genes are required for replication within the host cell. Similar to our findings for F. novicida, Salmonella (p)ppGpp-deficient mutants are attenuated in mice but able to induce a protective immune response (Pizarro-Cerda \& Tedin, 2004; Thompson et al., 2006; Song et al., 2004). In Legionella pneumophila, (p)ppGpp has been shown to trigger a cascade that leads to differentiation of replicating bacteria to a transmissible, non-replicating form, with the induction of virulence traits such as motility (Swanson \& Hammer, 2000). Stress-induced (p)ppGpp production in Helicobacter pylori is required for survival during acid exposure and aerobic shock (Mouery et al., 2006; Wells \& Gaynor, 2006), conditions typically encountered during the course of infection. In Francisella, intracellular replication and virulence are dependent on MglA and SspA, which regulates the FPI (Guina et al., 2007; Nano \& Schmerk, 2007; Charity et al., 2007). In this study, we have identified a global regulatory system that plays a role in $F$. novicida virulence, where a relA mutant had reduced survival in macrophage-like cells, and was attenuated more than 100fold in a BALB/c mouse model. We also confirmed that the reduced virulence observed was not a result of a growth defect, as has been described for other (p)ppGpp-deficient 
mutants (Fisher et al., 2005; Lemos et al., 2004; Okada et al., 2002). Uptake of $F$. novicida U112 $\Delta$ relA::cam into murine macrophages was similar to that of the wild-type and indicates that RelA is not involved in immune cell invasion. However, intracellular replication was impaired, suggesting that RelA has a regulatory role in Francisella, affecting the expression of genes whose products contribute to survival in nutrient-poor and hostile environments found within host cells. In addition, though unable to cause lethality in mice, U112 $\Delta$ relA::cam was able to stimulate a protective immune response affording greater than $60 \%$ survival against a homologous wild-type challenge.

In conclusion, we have demonstrated that $F$. novicida U112 responds to amino acid starvation in a RelA-dependent manner, resulting in elevated intracellular (p)ppGpp levels, and that RelA is required for virulence and resistance to stress. This study provides further insight into the understanding of gene regulation in F. tularensis.

\section{ACKNOWLEDGEMENTS}

We thank Dr M. Nelson and V. Patel for technical assistance, and Dr T. Laws for statistical advice.

\section{REFERENCES}

Abranches, J., Martinez, A. R., Kajfasz, J. K., Chavez, V., Garsin, D. A. \& Lemos, J. A. (2009). The molecular alarmone ( $p$ )ppGpp mediates stress responses, vancomycin tolerance and virulence in Enterococcus faecalis. J Bacteriol 191, 2248-2256.

Balzer, G. J. \& Mclean, R. J. C. (2002). The stringent response genes relA and spoT are important for Escherichia coli biofilms under slowgrowth conditions. Can J Microbiol 48, 675-680.

Baron, G. S. \& Nano, F. E. (1998). MgIA and MgIB are required for the intramacrophage growth of Francisella novicida. Mol Microbiol 29, 247-259.

Battesti, A. \& Bouveret, E. (2009). Bacteria possessing two RelA/ SpoT-like proteins have evolved a specific stringent response involving the acyl carrier protein-SpoT interaction. J Bacteriol 191, 616-624.

Braeken, K., Moris, M., Daniels, R., Vanderleyden, J. \& Michiels, J. (2006). New horizons for (p)ppGpp in bacterial and plant physiology. Trends Microbiol 14, 45-54.

Bugrysheva, J., Dobrikova, E. Y., Sartakova, M. L., Caimano, M. J., Daniels, T. J., Radolf, J. D., Godfrey, H. P. \& Cabello, F. C. (2003a). Characterization of the stringent response and $r l_{B b u}$ expression in Borrelia burgdorferi. J Bacteriol 185, 957-965.

Bugrysheva, J., Dobrikova, E. Y., Sartakova, M. L., Caimano, M. J., Daniels, T. J., Radolf, J. D., Godfrey, H. P. \& Cabello, F. C. (2003b). Characterization of the stringent response and $r l_{B b u}$ expression in Borrelia burgdorferi. J Bacteriol 185, 957-965.

Cashel, M. (1994). Detection of (p)ppGpp accumulation patterns in Escherichia coli mutants. In Methods in Molecular Genetics, vol. 3, Molecular Microbiology. Techniques, part A, pp. 341-356. Edited by K. W. Adolph. New York: Academic Press.

Chamberlain, R. E. (1965). Evaluation of live tularemia vaccine prepared in a chemically defined medium. Appl Microbiol 13, 232 235.
Charity, J. C., Costante-Hamm, M. M., Balon, E. L., Boyd, D. H., Rubin, E. J. \& Dove, S. L. (2007). Twin RNA polymerase-associated proteins control virulence gene expression in Francisella tularensis. PLoS Pathog 3, e84.

Dalebroux, Z. D., Edwards, R. L. \& Swanson, M. S. (2009). SpoT governs Legionella pneumophila differentiation in host macrophages. Mol Microbiol 71, 640-658.

Davis, B. D., Dulbecco, R., Eisen, H. N. \& Ginsberg, H. S. (1980). Microbiology. Hagerstown, MD: Harper and Row.

Ellis, J., Oyston, P. C. F., Green, M. \& Titball, R. W. (2002). Tularemia. Clin Microbiol Rev 15, 631-646.

Erickson, D. L., Lines, J. L., Pesci, E. C., Venturi, V. \& Storey, D. G. (2004). Pseudomonas aeruginosa relA contributes to virulence in Drosophila melanogaster. Infect Immun 72, 5638-5645.

Fisher, S. D., Reger, A. D., Baum, A. \& Hill, S. A. (2005). RelA alone appears essential for (p)ppGpp production when Neisseria gonorrhoeae encounters nutritional stress. FEMS Microbiol Lett 248, 1-8.

Gaynor, E. C., Wells, D. H., MacKichan, J. K. \& Falkow, S. (2005). The Campylobacter jejuni stringent response controls specific stress survival and virulence-associated phenotypes. Mol Microbiol 56, 8-27.

Gentry, D. R., Hernandez, V. J., Nguyen, L. H., Jensen, D. B. \& Cashel, M. (1993). Synthesis of the stationary-phase sigma-factor $\sigma^{\mathrm{s}}$ is positively regulated by ppGpp. J Bacteriol 175, 7982-7989.

Golovliov, I., Sjostedt, A., Mokrievich, A. \& Pavlov, V. (2003). A method for allelic replacement in Francisella tularensis. FEMS Microbiol Lett 222, 273-280.

Gray, C. G., Cowley, S. C., Cheung, K. K. M. \& Nano, F. E. (2002). The identification of five genetic loci of Francisella novicida associated with intracellular growth. FEMS Microbiol Lett 215, 53-56.

Guina, T., Radulovic, D., Bahrami, A. J., Bolton, D. L., Rohmer, L., Jones-Isaac, K. A., Chen, J., Gallagher, L. A., Gallis, B. \& other authors (2007). MglA regulates Francisella tularensis subsp novicida (Francisella novicida) response to starvation and oxidative stress. $J$ Bacteriol 189, 6580-6586.

Hammer, B. K. \& Swanson, M. S. (1999). Co-ordination of Legionella pneumophila virulence with entry into stationary phase by ppGpp. Mol Microbiol 33, 721-731.

Haralalka, S., Nandi, S. \& Bhadra, R. K. (2003). Mutation in the relA gene of Vibrio cholerae affects in vitro and in vivo expression of virulence factors. J Bacteriol 185, 4672-4682.

Ingraham, J. L., Maaloe, O. \& Neidhardt, F. C. (1983). Growth of the Bacterial Cell. Sunderland, MA: Sinauer Associates.

Jain, V., Kumar, M. \& Chatterji, D. (2006). ppGpp: stringent response and survival. J Microbiol 44, 1-10.

Jishage, M., Kvint, K., Shingler, V. \& Nystrom, T. (2002). Regulation of $\sigma$ factor competition by the alarmone ppGpp. Genes Dev 16, 12601270.

Kazmierczak, M. J., Wiedmann, M. \& Boor, K. J. (2005). Alternative sigma factors and their roles in bacterial virulence. Microbiol Mol Biol Rev 69, 527.

Kim, S., Watanabe, K., Suzuki, H. \& Watarai, M. (2005). Roles of Brucella abortus SpoT in morphological differentiation and intramacrophagic replication. Microbiology 151, 1607-1617.

Larsson, P., Oyston, P. C. F., Chain, P., Chu, M., Duffield, M. L., Gabbert, N. M., Fuxelius, H. H., Garcia, E., Halltorp, G. \& other authors (2005). The complete genome sequence of Francisella tularensis, the causative agent of tularemia. Nat Genet 37, 153-159.

Lauriano, C. M., Barker, J. R., Yoon, S. S., Nano, F. E., Arulanandam, B. P., Hassettt, D. J. \& Klose, K. E. (2004). MglA regulates transcription of virulence factors necessary for Francisella tularensis 
intraamoebae and intramacrophage survival. Proc Natl Acad Sci U S A 101, 4246-4249.

Lemos, J. A. C., Brown, T. A. \& Burne, R. A. (2004). Effects of RelA on key virulence properties of planktonic and biofilm populations of Streptococcus mutans. Infect Immun 72, 1431-1440.

Li, W., Liu, L., Chen, H. \& Zhou, R. (2009). Identification of Streptococcus suis genes preferentially expressed under iron starvation by selective capture of transcribed sequences. FEMS Microbiol Lett 292, 123-133.

Lindgren, H., Golovliov, I., Baranov, V., Ernst, R. K., Telepnev, M. \& Sjostedt, A. (2004). Factors affecting the escape of Francisella tularensis from the phagolysosome. J Med Microbiol 53, 953-958.

Magnusson, L. U., Farewell, A. \& Nystrom, T. (2005). ppGpp: a global regulator in Escherichia coli. Trends Microbiol 13, 236-242.

Manganelli, R. (2007). Polyphosphate and stress response in mycobacteria. Mol Microbiol 65, 258-260.

Meibom, K. L., Dubail, I., Dupuis, M., Barel, M., Lenco, J., Stulik, J., Golovliov, I., Sjostedt, A. \& Charbit, A. (2008). The heat-shock protein $\mathrm{ClpB}$ of Francisella tularensis is involved in stress tolerance and is required for multiplication in target organs of infected mice. Mol Microbiol 67, 1384-1401.

Milne, T. S., Michell, S. L., Diaper, H., Wikstrom, P., Svensson, K., Oyston, P. C. F. \& Titball, R. W. (2007). A $55 \mathrm{kDa}$ hypothetical membrane protein is an iron-regulated virulence factor of Francisella tularensis subsp. novicida U112. J Med Microbiol 56, 1268-1276.

Milton, D. L., O'Toole, R., Horstedt, P. \& Wolf-Watz, H. (1996). Flagellin $\mathrm{A}$ is essential for the virulence of Vibrio anguillarum. J Bacteriol 178, 1310-1319.

Mittenhuber, G. (2001). Comparative genomics and evolution of genes encoding bacterial (p)ppGpp synthetases/hydrolases (the Rel, RelA and SpoT proteins). J Mol Microbiol Biotechnol 3, 585600 .

Mohapatra, N. P., Soni, S., Bell, B. L., Warren, R., Ernst, R. K., Muszynski, A., Carlson, R. W. \& Gunn, J. S. (2007). Identification of an orphan response regulator required for the virulence of Francisella spp. and transcription of pathogenicity island genes. Infect Immun 75, 3305-3314.

Mouery, K., Rader, B. A., Gaynor, E. C. \& Guillemin, K. (2006). The stringent response is required for Helicobacter pylori survival of stationary phase, exposure to acid, and aerobic shock. J Bacteriol 188, $5494-5500$

Nano, F. E. \& Schmerk, C. (2007). The Francisella pathogenicity island. Ann N Y Acad Sci 1105, 122-137.

Nano, F. E., Zhang, N., Cowley, S. C., Klose, K. E., Cheung, K. K. M., Roberts, M. J., Ludu, J. S., Letendre, G. W., Meierovics, A. I. \& other authors (2004). A Francisella tularensis pathogenicity island required for intramacrophage growth. J Bacteriol 186, 6430-6436.

Nylund, A., Ottem, K. F., Watanabe, K., Karlsbakk, E. \& Krossoy, B. (2006). Francisella sp (Family Francisellaceae) causing mortality in Norwegian cod (Gadus morhua) farming. Arch Microbiol 185, 383392.

Ojha, A. K., Mukherjee, T. K. \& Chatterji, D. (2000). High intracellular level of guanosine tetraphosphate in Mycobacterium smegmatis changes the morphology of the bacterium. Infect Immun 68, 40844091.

Okada, Y., Makino, S., Tobe, T., Okada, N. \& Yamazaki, S. (2002). Cloning of rel from Listeria monocytogenes as an osmotolerance involvement gene. Appl Environ Microbiol 68, 1541-1547.

Ostland, V. E., Stannard, J. A., Creek, J. J., Hedrick, R. P., Ferguson, H. W., Carlberg, J. M. \& Westerman, M. E. (2006). Aquatic Francisellalike bacterium associated with mortality of intensively cultured hybrid striped bass Morone chrysops $\times$ M. saxatilis. Dis Aquat Organ 72, 135-145.

Oyston, P. C. F. (2008). Francisella tularensis: unravelling the secrets of an intracellular pathogen. J Med Microbiol 57, 921-930.

Parker, R. R., Steinhaus, E. A., Kohls, G. M. \& Jellison, W. L. (1951). Contamination of natural waters and mud with Pasteurella tularensis and tularemia in beavers and muskrats in the northwestern United States. Bull Natl Inst Health 193, 1-161.

Parkhill, J., Achtman, M., James, K. D., Bentley, S. D., Churcher, C., Klee, S. R., Morelli, G., Basham, D., Brown, D. \& other authors (2000). Complete DNA sequence of a serogroup A strain of Neisseria meningitidis Z2491. Nature 404, 502-506.

Pizarro-Cerda, J. \& Tedin, K. (2004). The bacterial signal molecule, ppGpp, regulates Salmonella virulence gene expression. Mol Microbiol 52, 1827-1844.

Potrykus, K. \& Cashel, M. (2008). (p)ppGpp: still magical? Annu Rev Microbiol 62, 35-51.

Primm, T. P., Andersen, S. J., Mizrahi, V., Avarbock, D., Rubin, H. \& Barry, C. E. (2000). The stringent response of Mycobacterium tuberculosis is required for long-term survival. J Bacteriol 182, 48894898.

Quarry, J. E., Isherwood, K. E., Michell, S. L., Diaper, H., Titball, R. W. \& Oyston, P. C. F. (2007). A Francisella tularensis subspecies novicida purF mutant, but not a purA mutant, induces protective immunity to tularemia in mice. Vaccine 25, 2011-2018.

Richards, M. I., Michell, S. L. \& Oyston, P. C. F. (2008). An intracellularly inducible gene involved in virulence and polyphosphate production in Francisella. J Med Microbiol 57, 1183-1192.

Rohmer, L., Brittnacher, M., Svensson, K., Buckley, D., Haugen, E., Zhou, Y., Chang, J., Levy, R., Hayden, H. \& other authors (2006). Potential source of Francisella tularensis live vaccine strain attenuation determined by genome comparison. Infect Immun 74, 68956906.

Sambrook, J., Fritsch, E. F. \& Maniatis, T. (1989). Molecular Cloning: a Laboratory Manual. Cold Spring Harbor, NY: Cold Spring Harbor Laboratory.

Simon, R., Priefer, U. \& Puhler, A. (1983). A broad host range mobilization system for in vivo genetic engineering: transposon mutagenesis in Gram-negative bacteria. Biotechnology (N Y) 1, 784791.

Sjostedt, A. (2006). Intracellular survival mechanisms of Francisella tularensis, a stealth pathogen. Microbes Infect 8, 561-567.

Song, M. Y., Kim, H. J., Kim, E. Y., Shin, M. S., Lee, H. C., Hong, Y. J., Rhee, J. H., Yoon, H., Ryu, S. \& other authors (2004). ppGppdependent stationary phase induction of genes on Salmonella pathogenicity island 1. J Biol Chem 279, 34183-34190.

Stepanovic, S., Vukovic, D., Dakic, I., Savic, B. \& Svabic-Vlahovic, M. (2000). A modified microtiter-plate test for quantification of staphylococcal biofilm formation. J Microbiol Methods 40, 175179.

Sureka, K., Dey, S., Datta, P., Singh, A. K., Dasgupta, A., Rodrigue, S., Basu, J. \& Kundu, M. (2007). Polyphosphate kinase is involved in stress-induced mprAB-sigE-rel signalling in mycobacteria. Mol Microbiol 65, 261-276.

Swanson, M. S. \& Hammer, B. K. (2000). Legionella pneumophila pathogenesis: a fateful journey from amoebae to macrophages. Annu Rev Microbiol 54, 567-613.

Taylor, C. M., Beresford, M., Epton, H. A. S., Sigee, D. C., Shama, G., Andrew, P. W. \& Roberts, I. S. (2002). Listeria monocytogenes relA and $h p t$ mutants are impaired in surface-attached growth and virulence. $J$ Bacteriol 184, 621-628. 
Tettelin, H., Saunders, N. J., Heidelberg, J., Jeffries, A. C., Nelson, K. E., Eisen, J. A., Ketchum, K. A., Hood, D. W., Peden, J. F. \& other authors (2000). Complete genome sequence of Neisseria meningitidis serogroup B strain MC58. Science 287, 1809-1815.

Thompson, A., Rolfe, M. D., Lucchini, S., Schwerk, P., Hinton, J. C. D. \& Tedin, K. (2006). The bacterial signal molecule, ppGpp, mediates the environmental regulation of both the invasion and intracellular virulence gene programs of Salmonella. J Biol Chem 281, 3011230121 .

Wells, D. H. \& Gaynor, E. C. (2006). Helicobacter pylori initiates the stringent response upon nutrient and $\mathrm{pH}$ downshift. J Bacteriol 188, $3726-3729$.
Williams, M. D., Ouyang, T. X. \& Flickinger, M. C. (1994). Starvationinduced expression of SspA and SspB - the effects of a null mutation in sspA on Escherichia coli protein synthesis and survival during growth and prolonged starvation. Mol Microbiol 11, 10291043.

Xiao, H., Kalman, M., Ikehara, K., Zemel, S., Glaser, G. \& Cashel, M. (1991). Residual guanosine $3^{\prime}, 5^{\prime}$-bispyrophosphate synthetic activity of relA null mutants can be eliminated by spoT null mutations. J Biol Chem 266, 5980-5990.

Edited by: T. P. Hatch 